\title{
Optimization of Batch Conditions and Application to Fixed-Bed Columns for a Sequential Technique of Total Color Removal Using "Greek Coffee" Residues as Materials for Real Dyeing Effluents
}

\author{
G. Z. Kyzas $^{1,2, *}$, N. K. Lazaridis ${ }^{2}$ and A. Ch. Mitropoulos ${ }^{1}$ \\ ${ }^{I}$ Dpt. of Petroleum and Natural Gas Technology, Technological Educational Institute of Kavala, GR-654 04 Kavala, Greece \\ ${ }^{2}$ Dpt. of Chemistry, Division of Chemical Technology, Aristotle University of Thessaloniki, GR-541 24 Thessaloniki, Greece
}

Received 6 May 2012; Accepted 20 December 2012

\begin{abstract}
In this study, the decolorization of industrial textile wastewaters was studied firstly in batch mode and after the optimization of these conditions, in fixed-bed columns using "Greek coffee" wastes (COF) as low-cost adsorbents. In this attempt, there is a cost potential given that there was no further modification of COF (just only washed with distilled water to remove dirt and colour, and dried in oven). Also, tests were realized both in synthetic and real textile wastewaters for comparative reasons. The optimum $\mathrm{pH}$ of adsorption was acidic $(\mathrm{pH}=2)$ for synthetic effluents, while experiments in free $\mathrm{pH}$ (non-adjusted) were carried out for real effluents. Equilibrium data were fitted to the Langmuir, Freundlich and Langmuir-Freundlich (L-F) model. The calculated maximum adsorption capacities (Qm) for total dye (reactive) removal at $25 \mathrm{oC}$ was $241 \mathrm{mg} / \mathrm{g}(\mathrm{pH}=2)$ and $179 \mathrm{mg} / \mathrm{g}(\mathrm{pH}=10)$. Thermodynamic parameters were also calculated $(\Delta \mathrm{H} 0, \Delta \mathrm{G} 0, \Delta \mathrm{S} 0)$. Kinetic data were fitted to the pseudo-first, -second and -third order model. The optimum agitation rate and the optimum $\mathrm{pH}$ for desorption were determined. The reuse potential showed 10 cycles of adsorptiondesorption, in which the reduction in adsorption percentages from the 1 st to 10 th cycle was $4 \%$ for COF adsorbents. Furthermore, experiments dealing the increase of mass of adsorbent showed a strong increase in total dye removal. To direct apply the optimized batch conditions, the same adsorbents were used in fixed-bed columns, performing a complete continuous adsorption/reuse system with low-cost.
\end{abstract}

Keywords: Industrial textile wastewaters; Coffee wastes; Batch studies; Fixed-bed columns; Adsorption; Dyes; Decolorization

\section{Introduction}

Wastewaters discharged from dye-houses can be one of the biggest contributors to aquatic pollution. The most studied dye classes, in dye bearing effluent treatment, are reactive and basic [1]. However, the larger amount of the dye loss from the dyeing process to the effluent is estimated to be 10 $50 \%$ for reactive dyes [2]; therefore, it is necessary firstly to treat/remove these reactive dyes. Furthermore, wastewaters containing dyes are very difficult to be treated, since the dyes are recalcitrant organic molecules, resistant to aerobic digestion, and stable to light, heat and oxidizing agents [3].

The dyeing process of cotton textiles using reactive dyes involves unit operations, such as (i) desizing, (ii) scouring, (iii) bleaching, (iv) dyeing, and (v) finishing [4,5]. The waste streams from each individual sub-operation are collected to an "equalization tank", where they are mixed and homogenized. In particular, the wastewater produced by the dyeing bath-reactor contains hydrolyzed reactive dyes, dyeing auxiliaries, and electrolytes $(60-100 \mathrm{~g} / \mathrm{L}$ of $\mathrm{NaCl}$ and $\mathrm{Na}_{2} \mathrm{CO}_{3}$ ). The latter are responsible for the high saline content of the wastewater, which exhibits high $\mathrm{pH}$ values (10-11) [4,5]. In a typical dyeing procedure with reactive

\footnotetext{
*E-mail address: idehaiohi@yahoo.com ISSN: 1791-2377@ 2012 Kavala Institute of Technology. All rights reserved.
}

dyes, 0.6-0.8 kg NaCl, 30-60 g dyestuff, and 70-150 L water are required for the dyeing of $1 \mathrm{~kg}$ of cotton [4]. So, the large volume of colorized effluents, after the dyeing process, has to be treated in some manner. Additionally, the research on textile effluent decolorization has been often focused on reactive dyes for three main reasons [5]: (i) reactive dyes represent an increasing market share, because they are used to dye cotton fibers, which makes up about half of the world's fiber consumption; (ii) a large fraction, typically around $30 \%$ of the applied reactive dyes, is wasted due to the dye hydrolysis in alkaline dye bath; (iii) conventional wastewater treatment plants have a low removal efficiency for reactive and other anionic soluble dyes, which leads to colored waterways $[4,6]$.

A typical effluent treatment is broadly classified into preliminary, primary, secondary, and tertiary stages $[4,7]$. The preliminary stage includes equalization and neutralization $[4,7]$. The primary stage involves screening, sedimentation, flotation, and flocculation. The secondary stage reduces the organic load and facilitate the physical/chemical separation (biological oxidation) [4,7], while the tertiary stage is focused on decolorization $[4,7,8]$. In the latter stage, the adsorption onto activated carbon is broadly used to limit the concentration of color in effluents [9]. Adsorption has been applied either in a single mode, mainly for dyes removal from synthetic wastewaters, or in a combinational mode for total cleaning of real dyeing wastewaters. 
Recently, many works have been studied for the development of effective and low-cost adsorbents. A published study of Crini [10] reported in details the main low-cost and non-conventional adsorbents for dyes removal (natural materials, biosorbents, waste materials from industry and agriculture). Some of the reported adsorbents include clay materials (bentonite, kaolinite), zeolites, siliceous material (silica beads, alunite, perlite), agricultural wastes (bagasse pith, maize cob, rice husk, coconut shell) [10-12], industrial waste products (waste carbon slurries, metal hydroxide sludge) (Crini, 2006; Konaganti et al., 2010), biosorbents (chitosan, peat, biomass) and others (starch, cyclodextrin, cotton) [10,13]. However, there is a lack of literature dealing with the possible application of coffee residues as adsorbents (i.e for metals) [14,15], and in particular as dye adsorbents [16-20].

In general, "coffee residues" are generally called the solid wastes discarded from the extraction process of instant coffee manufacturing, and the final residues originated from cafeterias. In the last years, the instant coffee industry has experienced a constant growth as instant coffee has become one of the most popular kinds of coffee drink by million of people around the world. As a consequence, large amounts of coffee grounds, which are the solid residues obtained during the processing of coffee powder with hot water or steam to prepare instant coffee, have been generated worldwide $(6,000,000 \mathrm{t} / \mathrm{yr})$ [21,22].

However, the screening of literature dealing with the "textile wastewaters" leads to many works on dye removal by adsorption from "synthetic effluents/mixtures" [10], while very few on "real (industrial) dyeing effluents/mixtures" [5,11,13].

The novelty of this study is the processing (decolorization) of real effluent originated directly from the dyeing bath, just before entering the equalization tank (so, only a small fraction $(\sim 10 \%)$ of the entire discharge volume will be treated, which means saving money and energy) [8] with industrial wastes (coffee residues) as adsorbents; the coffee wastes used were non-chemically modified. There is a high potential in this attempt given that despite the possible limited adsorption capacity of these materials, their cost is near to zero (the coffee wastes were only dried at ambient temperature and used for the adsorption experiments.

In the current work, the decolorization of real textile wastewaters and synthetic dye mixtures was performed in batch mode, studying the effect of: (i) $\mathrm{pH}$ on adsorption; (ii) agitation rate; (iii) initial total dye concentration; (iv) contact time; (v) temperature in equilibrium (isotherms); (vi) $\mathrm{pH}$ on desorption, and (vii) reuse in sequential cycles of adsorption-desorption. Then, the optimized batch systems were directly applied to fixed-bed systems to evaluate the possibility of using coffee wastes in columns as low-cost adsorbents. The flow rate, kinetics and reuse of adsorbents were also extensively studied in this mode.

\section{Materials and methods}

\subsection{Adsorbents- "Greek coffee" wastes (COF)}

The low-cost adsorbents used were non-modified industrial wastes of a special variety of coffee namely "Greek coffee" (abbreviated hereafter as COF) from cafeterias. The coffee residues were not chemically treated (without any modification to further improve their adsorptive ability), but just only washed with distilled water to remove dirt and colour, and dried at $105^{\circ} \mathrm{C}$ for $5 \mathrm{~h}$ in a convection oven. The residues used were in powder form $(475-525 \mu \mathrm{m})$ after sieving.

\subsection{Adsorbates - Dyes}

The real textile samples of wastewater from the dyeing reactor were kindly supplied by "Dyeing-Finishing mills of Thessaloniki, Greece" and composed of three reactive dyes: Remazol Red 3BS (abbreviated hereafter as RR, $\mathrm{C}_{31} \mathrm{H}_{19} \mathrm{ClN}_{7} \mathrm{Na}_{5} \mathrm{O}_{19} \mathrm{~S}_{6}, \mathrm{MW}=1136.31 \mathrm{~g} / \mathrm{mol}, \lambda_{\max }=588 \mathrm{~nm}$, $58 \% \mathrm{w} / \mathrm{w}$ ), Remazol Yellow gelb 3RS 133\% (abbreviated hereafter as RY, $\mathrm{C}_{28} \mathrm{H}_{20} \mathrm{ClN}_{9} \mathrm{Na}_{4} \mathrm{O}_{16} \mathrm{~S}_{5}, \mathrm{MW}=1026.25 \mathrm{~g} / \mathrm{mol}$, $\lambda_{\max }=419 \mathrm{~nm}, 60 \% \mathrm{w} / \mathrm{w}$ ), Remazol Blue RN (abbreviated hereafter as $\mathrm{RB}, \mathrm{C}_{22} \mathrm{H}_{162} \mathrm{Na}_{2} \mathrm{O}_{11} \mathrm{~S}_{3}, \mathrm{MW}=626.54 \mathrm{~g} / \mathrm{mol}$, $\left.\lambda_{\max }=541 \mathrm{~nm}, 56 \% \mathrm{w} / \mathrm{w}\right)$. The chemical structures of all dyes used are given in Fig. 1.

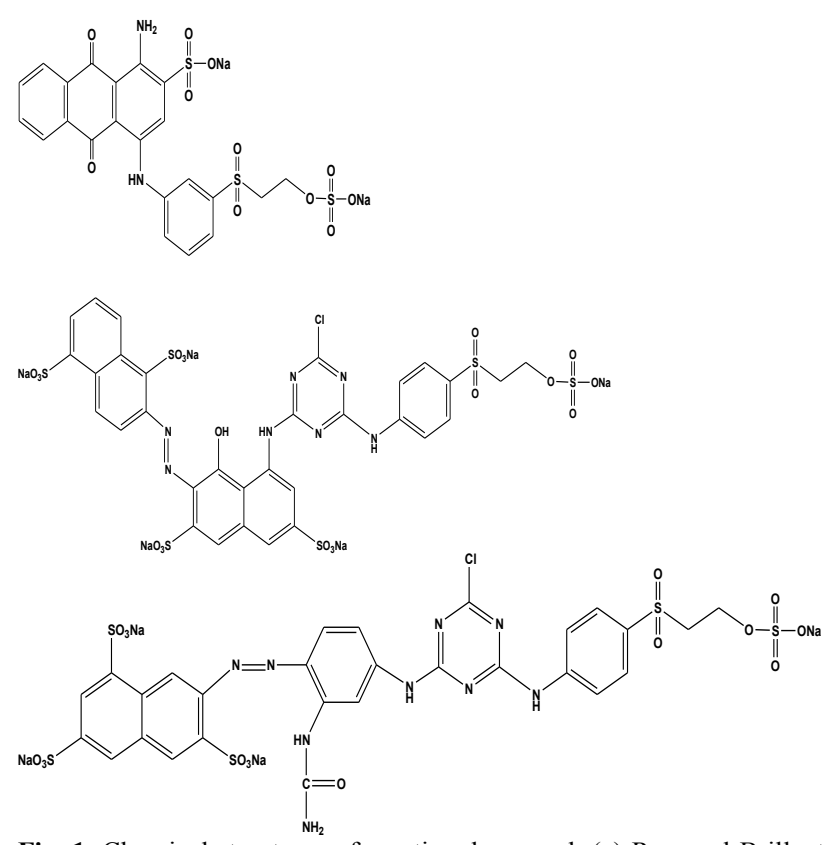

Fig. 1. Chemical structures of reactive dyes used: (a) Remazol Brillant Blue RN (RB); (b) Remazol Red 3BS (RR); (c) Remazol Yellow Gelb 3RS (RY).

Additionally, the same dyes in powder-form were supplied by DyStar and used as reagents for the preparation of synthetic dyeing samples. It should be stressed that the commercial dyes were supplied as a mixture of the active material and an inert product. This was taken into account and the concentrations in liquid and solid phase, which are presented in experimental results (Section 3), are actual (true) concentrations.

\subsection{Characterization of coffee wastes}

Characterization was realized to evaluate the surface chemistry and morphology of the low-cost materials used. The point of zero charge (PZC) was evaluated according to titration procedures described in literature [16,17,23]. Three aqueous solutions of different $\mathrm{pH}$ values $(3,6$ and 11$)$ were prepared. Several amounts of coffee wastes $(0.05 \%, 0.1 \%$, $0.5 \%, 1.0 \%, 3.0 \%, 7.0 \%$ and $10.0 \% \mathrm{w} / \mathrm{w}$ ) were added to 20 $\mathrm{mL}$ of each solution. The aqueous suspensions containing different amounts of the adsorbent were let to equilibrate for $24 \mathrm{~h}$ under agitation $(140 \mathrm{rpm})$ at $25{ }^{\circ} \mathrm{C}$. The $\mathrm{pH}$ of each solution was then measured. The PZC was determined as the 
converging $\mathrm{pH}$ value from the $\mathrm{pH}$ versus adsorbent mass curve.

The determination of surface functional groups was based on the Boehm titration method [24]. Aqueous solutions of $\mathrm{NaHCO}_{3}(0.10 \mathrm{~mol} / \mathrm{L}), \mathrm{Na}_{2} \mathrm{CO}_{3}(0.05 \mathrm{~mol} / \mathrm{L})$, $\mathrm{NaOH}(0.10 \mathrm{~mol} / \mathrm{L})$, and $\mathrm{HCl}(0.10 \mathrm{~mol} / \mathrm{L})$ were prepared. $50 \mathrm{~mL}$ of these solutions were added to vials containing $1 \mathrm{~g}$ of dry coffee samples, let to be shaken (140 rpm) until equilibrium $(24 \mathrm{~h})$, and then filtered. Five solution blanks (without the adsorbent) were also prepared. In this way, the number of the basic sites was calculated from the amount of $\mathrm{HCl}$ that reacted with the coffee adsorbents. The various free acidic groups were derived using the assumption that $\mathrm{NaOH}$ neutralizes carboxyl, lactone and phenolic groups, $\mathrm{Na}_{2} \mathrm{CO}_{3}$ neutralizes carboxyl and lactone and $\mathrm{NaHCO}_{3}$ neutralizes only carboxyl groups. The excess of base or acid was then determined by back titration using $\mathrm{NaOH}(0.10 \mathrm{~mol} / \mathrm{L})$ and $\mathrm{HCl}(0.10 \mathrm{~mol} / \mathrm{L})$ solutions [23].

Scanning electron microscopy (SEM) observations of the prepared particles were carried out using a JEOL JMS-840A scanning microscope equipped with an energy-dispersive $\mathrm{X}$ ray (EDX) Oxford ISIS 300 micro-analytical system. All of these surfaces were coated with a thin layer of carbon black to avoid charging under the electron beam.

The surface area was also determined with a Micromeritics BET (Brunauer, Emmett and Teller) surface area analyzer, model TriStar 3000 , by means of adsorption of ultra pure nitrogen.

\subsection{Adsorption-desorption experiments}

Before the adsorption experiments, the real dyeing effluent supplied was analyzed (based on methods described in 2.5. Section) and the concentrations of each dye were found to be $197 \mathrm{mg} / \mathrm{L}$ RR, $223 \mathrm{mg} / \mathrm{L} \mathrm{RY}$, and $280 \mathrm{mg} / \mathrm{L} \mathrm{RB}$ (RR, 28\%; RY, $32 \%$; RB, $40 \%$ ). Based on this, the synthetic effluent (mixture) was composed of the same dye concentrations along with $1 \mathrm{~mol} / \mathrm{L} \mathrm{NaCl}$ ionic strength [4].

The effect of $\mathrm{pH}$ was conducted by mixing $1 \mathrm{~g} / \mathrm{L}$ of adsorbent with $50 \mathrm{~mL}$ of synthetic and real sample (total dye concentration $700 \mathrm{mg} / \mathrm{L}$ : $197 \mathrm{mg} / \mathrm{L} \mathrm{RR}, 223 \mathrm{mg} / \mathrm{L} \mathrm{RY}$, and $280 \mathrm{mg} / \mathrm{L} \mathrm{RB}$ ). The $\mathrm{pH}$ value, ranging between 2 and 12 , was kept constant throughout the adsorption process by micro-additions of $\mathrm{HNO}_{3}(0.01 \mathrm{~mol} / \mathrm{L})$ or $\mathrm{NaOH}(0.01$ $\mathrm{mol} / \mathrm{L}$ ). The suspension was shaken for $24 \mathrm{~h}$ (agitation rate $=140 \mathrm{rpm}$ ) into a water bath to control the temperature at $25{ }^{\circ} \mathrm{C}$ (Julabo SW-21C). The optimum $\mathrm{pH}$ found for synthetic dye mixture was $\mathrm{pH}=2$ (see Section 3.2.1).

Kinetic experiments were performed by mixing $1 \mathrm{~g} / \mathrm{L}$ of COF with $50 \mathrm{~mL}$ of real and synthetic dyeing mixtures (total dye concentration $700 \mathrm{mg} / \mathrm{L}$ ). The suspensions were shaken for $24 \mathrm{~h}$ at non-adjusted (natural) $\mathrm{pH}(\sim 10)$ in water bath at $25{ }^{\circ} \mathrm{C}$ (agitation rate $=140 \mathrm{rpm}$ ). Samples were collected at fixed intervals (5-30 $\mathrm{min}, 1-24 \mathrm{~h}$ ). The following three equations (pseudo-first order, Eq. (1); pseudo-second order, Eq. (2); pseudo-third order, Eq. (3)) were selected to fit the experimental kinetic data [25]:

$$
\begin{aligned}
& C_{t}=C_{0}-\left(C_{0}-C_{e}\right)\left(1-e^{-k_{1} t}\right) \\
& C_{t}=C_{0}-\left(C_{0}-C_{e}\right)\left(1-\frac{1}{1+k_{2} t}\right)
\end{aligned}
$$

$$
\mathrm{C}_{\mathrm{t}}=\mathrm{C}_{0}-\left(\mathrm{C}_{0}-\mathrm{C}_{\mathrm{e}}\right)\left(1-\frac{1}{\left(1+2 \mathrm{k}_{3} \mathrm{t}\right)^{1 / 2}}\right)
$$

where $\mathrm{k}_{1}, \mathrm{k}_{2}, \mathrm{k}_{3}\left(\mathrm{~min}^{-1}\right)$ are the rate constants for the pseudofirst, -second and -third order adsorption kinetic model, respectively, and $\mathrm{C}_{0}, \mathrm{C}_{\mathrm{t}}, \mathrm{C}_{\mathrm{e}}(\mathrm{mg} / \mathrm{L})$ are the initial, transient and equilibrium total concentrations of dye in the aqueous solution, respectively.

The effect of agitation rate on equilibrium was observed by mixing $1 \mathrm{~g} / \mathrm{L}$ of adsorbent with $50 \mathrm{~mL}$ of $700 \mathrm{mg} / \mathrm{L}$ real dyeing effluent. The suspensions were shaken for $24 \mathrm{~h}$ at natural $\mathrm{pH}(\sim 10)$ in water bath at $25^{\circ} \mathrm{C}$. The rate of agitation was ranged from 60 to $180 \mathrm{rpm}$.

The effect of total initial dye concentration (synthetic samples) on equilibrium was observed by mixing $1 \mathrm{~g} / \mathrm{L}$ of COF with $50 \mathrm{~mL}$ of dye solutions of different initial dye concentrations (0-1000 mg/L). Given that the concentrations of each dye in the real dyeing sample were analyzed and found to be $197 \mathrm{mg} / \mathrm{L} \mathrm{RR}, 223 \mathrm{mg} / \mathrm{L} \mathrm{RY}$, and $280 \mathrm{mg} / \mathrm{L} \mathrm{RB}$, the same proportion was adopted to the preparation of synthetic effluent for the experiments of the effect of total initial dye concentration. The suspensions were shaken for $24 \mathrm{~h}$ at $\mathrm{pH}=2$ (optimum $\mathrm{pH}$ found) and $\mathrm{pH}=10$ (natural/free $\mathrm{pH}$ value of real textile effluent) in water bath at $25{ }^{\circ} \mathrm{C}$ (agitation rate $=140 \mathrm{rpm}$ ). The equilibrium data resulted were fitted to the Langmuir (Eq. (4)) [26], Freundlich (Eq. (5)) [27], and Langmuir - Freundlich (L-F) (Eq. (6)) isotherm model [28], expressed by the following respective equations:

$$
\begin{aligned}
& Q_{e}=\frac{Q_{m} K_{L} C_{e}}{1+K_{L} C_{e}} \\
& Q_{e}=K_{F} C_{e}^{1 / n} \\
& Q_{e}=\frac{Q_{m}\left(K_{L F} C_{e}\right)^{b}}{1+\left(K_{L F} C_{e}\right)^{b}}
\end{aligned}
$$

where $\mathrm{Q}_{\mathrm{e}}(\mathrm{mg} / \mathrm{g})$ is the equilibrium dye concentration in the solid phase; $\mathrm{Q}_{\mathrm{m}}(\mathrm{mg} / \mathrm{g})$ is the maximum amount of adsorption; $\mathrm{K}_{\mathrm{L}}(\mathrm{L} / \mathrm{mg})$ is the Langmuir adsorption equilibrium constant; $\mathrm{K}_{\mathrm{F}}\left(\mathrm{mg}^{1-1 / \mathrm{n}} \mathrm{L}^{1 / \mathrm{n}} / \mathrm{g}\right)$ is the Freundlich constant representing the adsorption capacity, $\mathrm{n}$ is the constant depicting the adsorption intensity, $\mathrm{K}_{\mathrm{LF}}(\mathrm{L} / \mathrm{mg})^{1 / \mathrm{b}}$ is the Langmuir-Freundlich constant, and $b$ is the LangmuirFreundlich heterogeneity constant. The amount of total dye uptake at equilibrium $\mathrm{Q}_{\mathrm{e}}(\mathrm{mg} / \mathrm{g})$ was calculated using the mass balance equation (Eq. (7)):

$$
\mathrm{Q}_{\mathrm{e}}=\frac{\left(\mathrm{C}_{0}-\mathrm{C}_{\mathrm{e}}\right) \mathrm{V}}{\mathrm{m}}
$$

where $\mathrm{m}(\mathrm{g})$ is the mass of adsorbent; $\mathrm{V}(\mathrm{L})$ the volume of adsorbate; $\mathrm{C}_{0}$ and $\mathrm{C}_{\mathrm{e}}(\mathrm{mg} / \mathrm{L})$ are the initial and equilibrium dye concentrations in the liquid phase, respectively.

Based on the equilibrium data of isotherms, thermodynamic parameters were calculated. The Gibbs free energy change, $\Delta \mathrm{G}^{0}(\mathrm{~kJ} / \mathrm{mol})$, of the adsorption process is related to the equilibrium constant, $\mathrm{K}_{\mathrm{c}}(-)$, by the Van't Hoff equation (Eq. (8)) [29]:

$\Delta \mathrm{G}^{0}=-\mathrm{R} \mathrm{T} \ln \left(\mathrm{K}_{\mathrm{c}}\right)$ 
where $\mathrm{R}(=8.314 \mathrm{~J} / \mathrm{mol} \mathrm{K})$ is the universal gas constant;

The constant $\mathrm{K}_{\mathrm{c}}$ can be calculated from Eq. (9):

$\mathrm{K}_{\mathrm{c}}=\frac{\mathrm{C}_{\mathrm{s}}}{\mathrm{C}_{\mathrm{e}}}$

where $\mathrm{C}_{\mathrm{s}}(\mathrm{mg} / \mathrm{L})$ is the amount adsorbed on solid at equilibrium.

It is also related to the change in entropy, $\Delta \mathrm{S}^{0}(\mathrm{~kJ} / \mathrm{mol} \mathrm{K})$ and the heat of adsorption, $\Delta \mathrm{H}^{0}(\mathrm{~kJ} / \mathrm{mol})$, at a constant temperature, $\mathrm{T}(\mathrm{K})$, as follows (Eq. (10)):

$$
\Delta G^{0}=\Delta H^{0}-T \Delta S^{0}
$$

The combination of the above equations (Eqs. (8)-(10)) resulted in Eq. (11):

$$
\ln \left(\mathrm{K}_{\mathrm{c}}\right)=\frac{\Delta \mathrm{S}^{0}}{\mathrm{R}}-\frac{\Delta \mathrm{H}^{0}}{\mathrm{RT}}
$$

The values of $\Delta \mathrm{H}^{0}$ and $\Delta \mathrm{S}^{0}$ were calculated from the slop and intercept of the plot between $\ln \left(\mathrm{K}_{\mathrm{c}}\right)$ versus $(1 / \mathrm{T})$.

In the case of real samples, where the initial dye concentration cannot be varied, the key-factor is the determination of the mass of adsorbent (which is able to decolorize sufficiently the dyeing solutions). To determine the effect of the mass of adsorbent, experiments were carried out varying the dosage $(1-10 \mathrm{~g} / \mathrm{L})$ and keeping constant all the other parameters: $\mathrm{pH}($ free $)=10$; total dye concentration $700 \mathrm{mg} / \mathrm{L}$ (as calculated from dye analysis), $25^{\circ} \mathrm{C} ; 140 \mathrm{rpm}$; $24 \mathrm{~h}$.

After adsorption experiments (where COF adsorbents were exposed to $700 \mathrm{mg} / \mathrm{L}$ of real textile wastewaters; 25 $\left.{ }^{\circ} \mathrm{C} ; \mathrm{pH} \sim 10 ; 24 \mathrm{~h} ; 140 \mathrm{rpm}\right)$, the samples were collected and filtered, using fixed pore-sized membranes. A small fraction of the dye $(1-2 \%)$ and the adsorbent $(1 \%)$ were retained on the filter membrane; these small variations due to filtration were neglected. To determine the optimum desorption $\mathrm{pH}$ value of the dye-loaded adsorbents, experiments were realized by mixing the collected (after adsorption) amount of dye-loaded adsorbents $(0.05 \mathrm{~g})$ with aqueous solutions of 50 $\mathrm{mL}$ (same volume as in the adsorption step) over a $\mathrm{pH}$ range between 2 and 12 , at $25{ }^{\circ} \mathrm{C}$ for $24 \mathrm{~h}$ (agitation rate $=140$ $\mathrm{rpm}$ ). To determine the reusability of the COF adsorbents, 10 sequential adsorption-desorption cycles were repeated, using the same adsorbents and following the experimental procedures described above in the optimum conditions found.

\subsection{Analysis}

The dye content of samples was measured spectrophotometrically (UV-Vis, model U-2000, Hitachi). The effect of $\mathrm{pH}$ and aquatic environment on both the calibration curves and $\lambda_{\max }$ (maximum wavelength of each dye) were studied, but no significant deviation was observed. For synthetic dyeing mixtures, the dye content (expressed in units of concentration, $\mathrm{mg} / \mathrm{L}$ ) was calculated as described below:

The absorbance of the mixture was measured in the three wavelengths of maximum absorbencies of dyes $\left(\lambda_{\max , \mathrm{RR}}\right.$, $\left.\lambda_{\max , \mathrm{RB}}, \lambda_{\max , \mathrm{RY}}\right)$. The molar absorbtivity/extinction coefficients $\mathrm{E}\left(\mathrm{L} \mathrm{mol}^{-1} \mathrm{~cm}^{-1}\right)$ for the three dyes was calculated from the Lambert-Beer law $(A=E \times Z \times C)$, where $Z(\mathrm{~cm})$ is the path length of the cell. The resulting $3 \times 3$ equation system (expressed by Eqs. (12)-(14)) gives the residual concentration of each reactive dye [30,31]:

$$
\begin{aligned}
& \mathrm{A}_{\lambda 1}=\mathrm{E}_{\lambda 1, \mathrm{RY}} \times \mathrm{Z} \times \mathrm{C}_{\mathrm{RY}}+\mathrm{E}_{\lambda 1, \mathrm{RB}} \times \mathrm{Z} \times \mathrm{C}_{\mathrm{RB}}+\mathrm{E}_{\lambda 1, \mathrm{RR}} \times \mathrm{Z} \times \mathrm{C}_{\mathrm{RR}} \\
& \mathrm{A}_{\lambda 2}=\mathrm{E}_{\lambda 2, \mathrm{RY}} \times \mathrm{Z} \times \mathrm{C}_{\mathrm{RY}}+\mathrm{E}_{\lambda 2, \mathrm{RB}} \times \mathrm{Z} \times \mathrm{C}_{\mathrm{RB}}+\mathrm{E}_{\lambda 2, \mathrm{RR}} \times \mathrm{Z} \times \mathrm{C}_{\mathrm{RR}} \\
& \mathrm{A}_{\lambda 3}=\mathrm{E}_{\lambda 3, \mathrm{RY}} \times \mathrm{Z} \times \mathrm{C}_{\mathrm{RY}}+\mathrm{E}_{\lambda 3, \mathrm{RB}} \times \mathrm{Z} \times \mathrm{C}_{\mathrm{RB}}+\mathrm{E}_{\lambda 3, \mathrm{RR}} \times \mathrm{Z} \times \mathrm{C}_{\mathrm{RR}}
\end{aligned}
$$

where $A_{\lambda 1}, A_{\lambda 2}$, and $A_{\lambda 3}$ are the absorbencies of the mixture at $\lambda_{\max }$ of RY dye $\left(\lambda_{1}=588 \mathrm{~nm}\right), \mathrm{RR}\left(\lambda_{2}=541 \mathrm{~nm}\right)$, and RB $\left(\lambda_{3}=419 \mathrm{~nm}\right)$, respectively. $\mathrm{E}_{\lambda 1, \mathrm{RY}}, \mathrm{E}_{\lambda 1, \mathrm{RB}}, \mathrm{E}_{\lambda 1, \mathrm{RR}}$ the absorbance coefficients of pure RY, RB, RR at $t \lambda_{\max }$ of RY dye. $E_{\lambda 2, R Y}, E_{\lambda 2, R B}, E_{\lambda 2, R R}$ the absorbance coefficients of pure $\mathrm{RY}, \mathrm{RB}, \mathrm{RR}$ at $\lambda_{\max }$ of RR dye. $\mathrm{E}_{\lambda 3, \mathrm{RY}}, \mathrm{E}_{\lambda 3, \mathrm{RB}}, \mathrm{E}_{\lambda 3, \mathrm{RR}}$ the absorbance coefficients of pure RY, RB, RR at $\lambda_{\max }$ of RB dye.

To obtain a direct application to the legislation limits, apart from concentration units $(\mathrm{mg} / \mathrm{L})$, the residual total dye concentration was expressed in ADMI units. Briefly, this method involves measuring the absorbance of samples [7,32], after filtration at sets of 30 wavelengths (usually 400$700 \mathrm{~nm}$ ) depending on the accuracy required to generate the CIE (Commission International de l'Eclairage) Tristimulus Values, $X, Y$ and $Z$. Tristimulus values for samples are $X_{s}$, $Y_{s}$, and $Z_{s}$; for standards are $X_{r}, Y_{r}$, and $Z_{r}$; and for distilled water are $X_{c}, Y_{c}, Z_{c}$. These are converted by the use of published tables to values called Munsell values. Munsell values for samples are $\mathrm{V}_{\mathrm{xs}}, \mathrm{V}_{\mathrm{ys}}, \mathrm{V}_{\mathrm{zs}}$; for standards $\mathrm{V}_{\mathrm{xr}}, \mathrm{V}_{\mathrm{yr}}, \mathrm{V}_{\mathrm{zr}}$ ; and for distilled water $\mathrm{V}_{\mathrm{xc}}, \mathrm{V}_{\mathrm{yc}}, \mathrm{V}_{\mathrm{zc}}$. From the Munsell values the Adams-Nickerson Color Difference (DE) is calculated from the Eq. (15) [33]:

$\mathrm{DE}=\left[\left(0.23 \Delta\left(\mathrm{V}_{\mathrm{y}}\right)\right)^{2}+\left(\Delta\left(\mathrm{V}_{\mathrm{x}}-\mathrm{V}_{\mathrm{y}}\right)\right)^{2}+\left(0.4 \Delta\left(\mathrm{V}_{\mathrm{y}}-\mathrm{V}_{\mathrm{z}}\right)\right)^{2}\right]^{1 / 2}$

where:

$$
\begin{aligned}
& \Delta\left(\mathrm{V}_{\mathrm{y}}\right)=\mathrm{V}_{\mathrm{ys}}-\mathrm{V}_{\mathrm{yc}} \\
& \Delta\left(\mathrm{V}_{\mathrm{x}}-\mathrm{V}_{\mathrm{y}}\right)=\left(\mathrm{V}_{\mathrm{xs}}-\mathrm{V}_{\mathrm{ys}}\right)-\left(\mathrm{V}_{\mathrm{xs}}-\mathrm{V}_{\mathrm{yc}}\right) \\
& \Delta\left(\mathrm{V}_{\mathrm{y}}-\mathrm{V}_{\mathrm{z}}\right)=\left(\mathrm{V}_{\mathrm{ys}}-\mathrm{V}_{\mathrm{zs}}\right)-\left(\mathrm{V}_{\mathrm{yc}}-\mathrm{V}_{\mathrm{zc}}\right)
\end{aligned}
$$

The DE values of a series of APHA platinum-cobalt standards is plotted against the corresponding ADMI values to give a calibration plot and the DE value of samples read against this plot to obtain the ADMI value of the sample.

\section{Results and discussion}

\subsection{Characterization of coffee wastes}

The composition of COF was determined as $44 \%$ water, $12 \%$ protein, $14 \%$ lipids, $25 \%$ carbohydrates and $5 \%$ ash. According to Boehm method [24], the functional groups at the surface of COF were carboxylic $0.97 \mathrm{mmol} / \mathrm{g}_{\mathrm{COF}}$ and basic $0.93 \mathrm{mmol} / \mathrm{g}_{\mathrm{COF}}$, followed by phenolic $0.14 \mathrm{mmol} / \mathrm{g}_{\mathrm{COF}}$ and 0.11 lactonic $\mathrm{mmol} / \mathrm{g}_{\mathrm{COF}}$.

Fig. 2 presents the morphology of COF according to SEM micrographs taken. It is obvious that its surface was not smooth, but full of cavities. These cavities can be characterized as channels onto the surface of COF instead of 
pores [34], given the small surface area calculated from BET analysis $\left(\sim 2.3 \mathrm{~m}^{2} / \mathrm{g}\right)$.

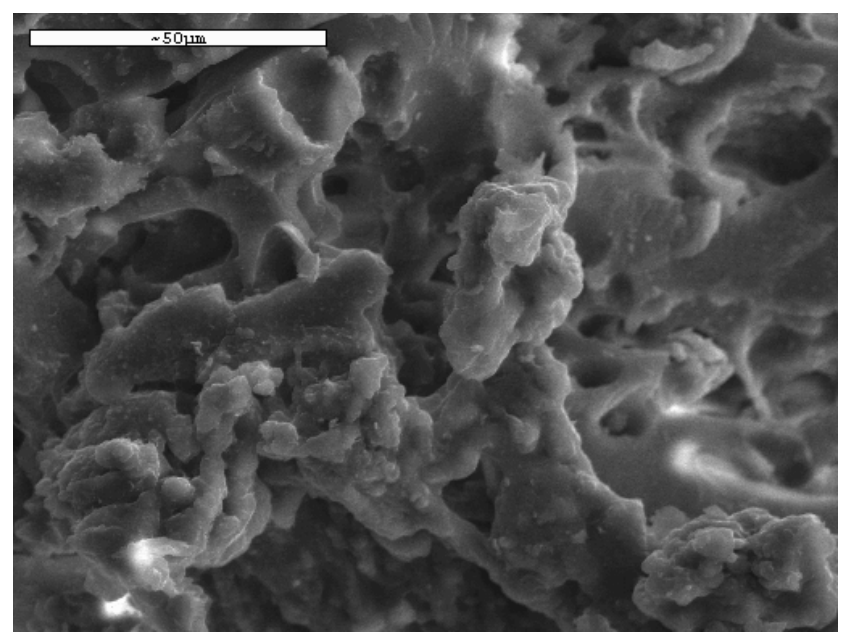

Fig. 2. Scanning Electron Micrograph of the COF

The energy dispersive X-ray microanalysis (SEM/EDX) of the coffee wastes indicates mainly the presence of oxygen $(64.11 \%)$ and carbon $(30.59 \%)$. Also a variety of other elements $(5.30 \%)$ was also determined mainly as admixtures (K, Na, Mg, P, S).

The experimental titration curves for PZC determination are presented in Fig. 3. These results indicated the PZC values in the range of 3.3-3.5. So, for $\mathrm{pH}$ values above of 3.5 , a predominant negatively charged surface of COF is occurred. At lower $\mathrm{pH}$ values, the surface charge may get mainly positively charged. The aforementioned consideration was proved and extensively explained in line with the adsorption mechanism of dyes onto coffee surface in previously published works [16,17,20,34].

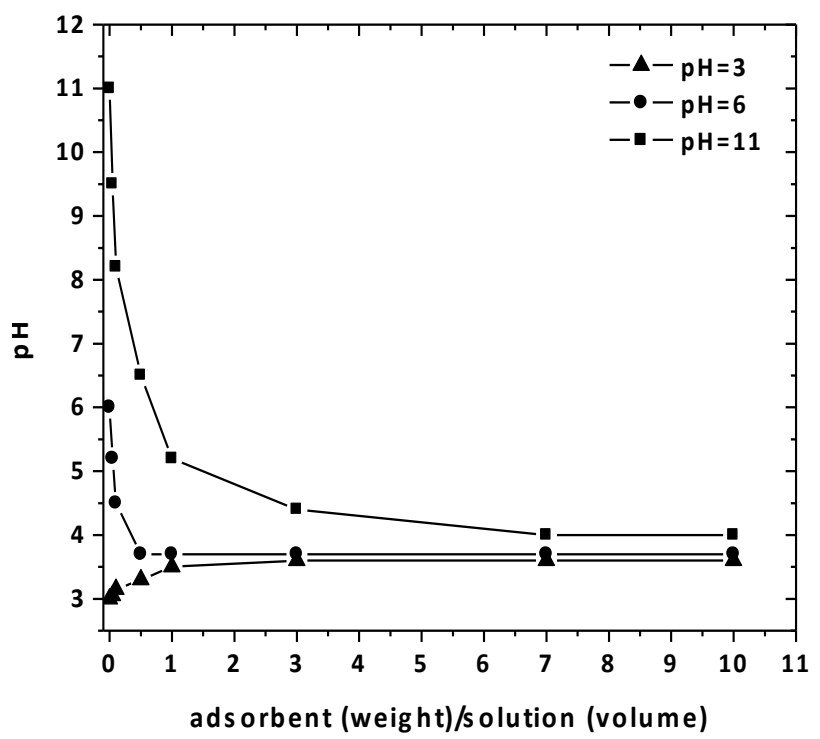

Fig. 3. Determination of the point of zero charge (PZC) of the COF.

\subsection{Batch systems}

\subsubsection{Effect of pH}

One of the most important factors, affecting the capacity of an adsorbent in wastewater treatment, is $\mathrm{pH}$. The effect of $\mathrm{pH}$ on decolorization from $\mathrm{COF}$ is shown in Fig. 4. From a first point of view, all curves presented the same trend both for real and synthetic dyeing wastewaters. The maximum dye removal percentage was observed for adjusted $\mathrm{pH}=2$ (synthetic, 30\%; real, 28\%). So, it becomes obvious that the total dye removal percentages (quantitatively) were lower in the case of real effluents (see Fig. 4), due to the presence of dyeing auxiliaries [4]. However, the change in percentages between real and synthetic effluents was only $2 \%$. In general, the higher dye uptakes were showed in acidic $\mathrm{pH}-$ region, due to the acidic nature of reactive dyes (this type of dyes contains sulfonate groups, as seen in Fig. 1) acidic $\mathrm{pH}$ values [35], the surface of COF can be easily charged positively due to the excess of $\mathrm{H}^{+}$groups in solution. Therefore, the positively charged sites of COF can interact with the negative sulfonate groups of reactive dyes, forming a strong bond between adsorbent and dye. The most promising finding was that the dye removal percentages of COF was changed only $5 \%$ (from $28 \%$ to $23 \%$ ) at the nature $\mathrm{pH}$ value of the real textile effluent $(\sim 10)$. The dye removal percentage at even $\mathrm{pH}=10$ could be attributed to a combination of decreased electrostatic and other interactions, as van der Waals forces, hydrogen bonding and pi-pi interactions $[5,34,36]$. The aforementioned mechanism is already explained in previous work [34].

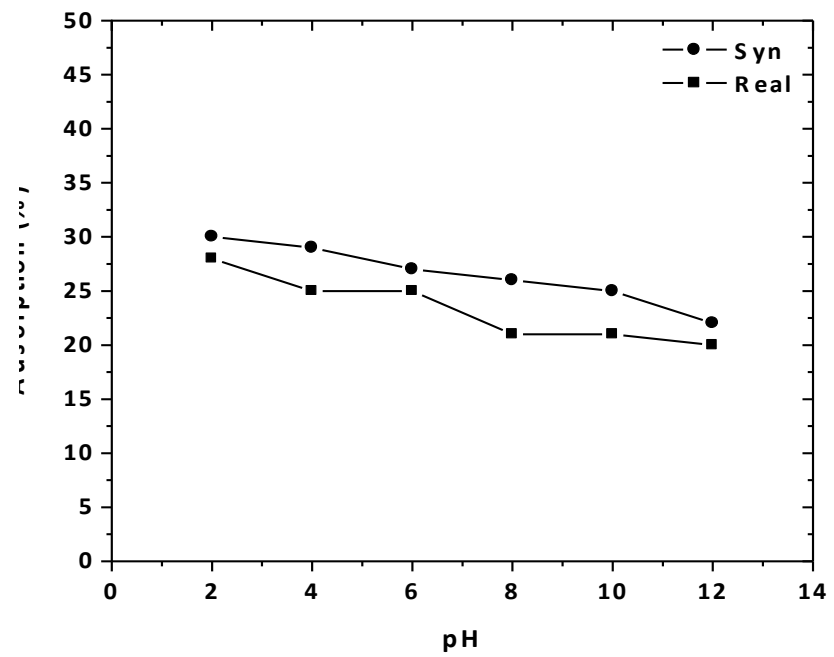

Fig. 4. Effect of $\mathrm{pH}$ on decolorization of real and synthetic dyeing solutions with $\mathrm{COF}(\mathrm{pH}=2-12 ; 1 \mathrm{~g} / \mathrm{L}$ adsorbent; $700 \mathrm{mg} / \mathrm{L}$ total dye concentration; $\mathrm{T}=25^{\circ} \mathrm{C} ; 140 \mathrm{rpm} ; 24 \mathrm{~h}$ contact).

So, further adsorption experiments (kinetics, agitation rate, adsorbent's dosage) were performed at the natural $\mathrm{pH}$ value ( $\mathrm{pH} \sim 10)$ for real samples of wastewaters, because: (i) $\mathrm{pH}=10$ is the original alkalinity of textile effluents, (ii) additional cost will be avoided due to the non $\mathrm{pH}$-regulation, (iii) dye removal at this $\mathrm{pH}$ still presents only $5 \%$ decrease with respect to $\mathrm{pH}=2$ for $\mathrm{COF}$ (see Fig. 4).

\subsubsection{Kinetics}

Fig. 5 illustrates the effect of contact time on decolorization (dyes adsorption) with the low-cost materials used. The plots (synthetic and real sample) could be divided in three zones: (i) 0-30 min, which indicated the instantaneous adsorption of dyes, suggesting rapid external diffusion and surface adsorption; (ii) 30-180 min, showed a gradual equilibrium, and (iii) 3-24 h, indicated the plateau of the equilibrium state [36]. It can be seen that the adsorption was rapid at the initial stage of the contact, but it gradually slowed down until the equilibrium. The fast adsorption at the initial stage can be attributed to the fact that a large number of surface sites are available for adsorption. After a lapse of time, the 
remaining surface sites are difficult to be occupied because of the repulsion between the solute molecules of the solid and bulk phases make it took long time to reach equilibrium [19].

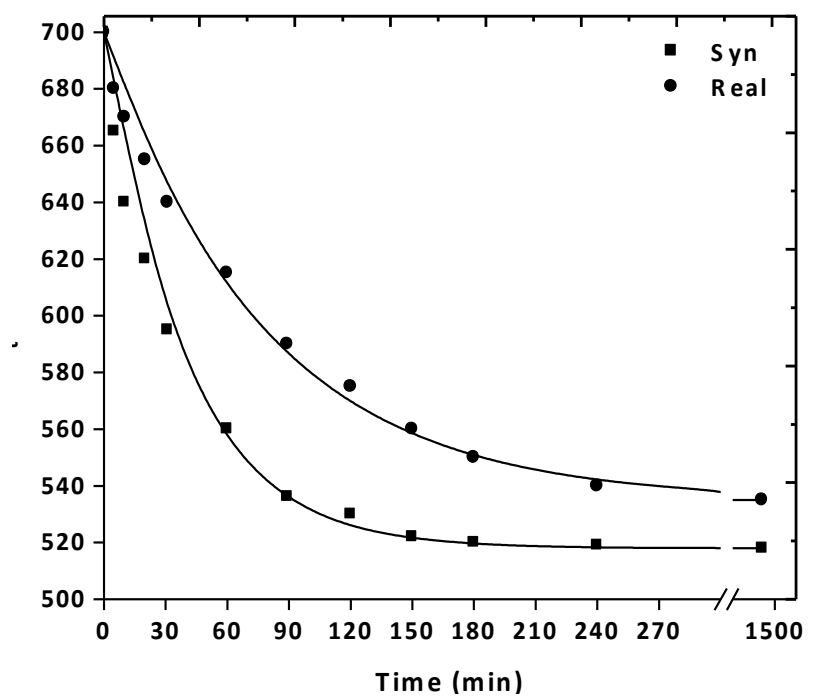

Fig. 5. Effect of contact time on decolorization of real and synthetic dyeing solutions with $\mathrm{COF}$ ( $\mathrm{pH}=$ free, $700 \mathrm{mg} / \mathrm{L}$ total dye concentration; $1 \mathrm{~g} / \mathrm{L}$ adsorbent; $\mathrm{T}=25^{\circ} \mathrm{C} ; 140 \mathrm{rpm} ; 5 \mathrm{~min}-24 \mathrm{~h}$ contact).

Table 1 presents the kinetic parameters resulted from the fitting of the pseudo-first, -second and -third order equation to the experimental kinetic data. Based on the correlation coefficients $\left(\mathrm{R}^{2}\right)$ exported, the best fitting (for real dyeing sample) was observed for the pseudo-first order equation $\left(\mathrm{R}^{2}=0.994\right)$, while the pseudo-second $\left(\mathrm{R}^{2}=0.967\right)$, and pseudo-third $\left(\mathrm{R}^{2}=0.889\right)$ order equations presented enough lower coefficients. The kinetic rate was established with the parameter " $\mathrm{k}$ " calculated $\left(\mathrm{k}_{1}=0.013 \mathrm{~min}^{-1}\right)$. Comparing with the respective kinetic parameter for synthetic sample, it is clear that its decolorization "runs" faster $\left(\mathrm{k}_{1}=0.021 \mathrm{~min}^{-1}\right)$, which can be easily attributed to the existence of auxiliaries in real sample. The excess of impurities and dye auxiliaries prevents the rapid removal of dye molecules and their binding onto COF surface.

Table 1

Kinetic constants for the decolorization of real and synthetic effluent with $\mathrm{COF}$ at $25^{\circ} \mathrm{C}$.

\begin{tabular}{lcccccc}
\hline & \multicolumn{2}{c}{$\begin{array}{c}\text { Pseudo-first } \\
\text { order }\end{array}$} & \multicolumn{2}{c}{$\begin{array}{c}\text { Pseudo-second } \\
\text { order }\end{array}$} & \multicolumn{2}{c}{$\begin{array}{c}\text { Pseudo-third } \\
\text { order }\end{array}$} \\
\cline { 2 - 8 } Sample & $\mathrm{k}_{1}$ & $\mathrm{R}^{2}$ & $\mathrm{k}_{2}$ & $\mathrm{R}^{2}$ & $\mathrm{k}_{3}$ & $\mathrm{R}^{2}$ \\
\hline Real & 0.013 & - & $\mathrm{min}^{-1}$ & - & $\mathrm{min}^{-1}$ & - \\
Synthetic & 0.021 & 0.994 & 0.026 & 0.967 & 0.051 & 0.889 \\
\hline
\end{tabular}

\subsubsection{Effect of agitation rate}

The effect of agitation rate on decolorization of real and synthetic textile effluent is presented in Fig. 6. The agitation curves were similar: increasing the agitation rate, an increase in total dye removal occurs. However, over $140 \mathrm{rpm}$, there is no any increase. For low agitation speed $60-80 \mathrm{rpm}$, the dye molecules can hard "find" the possible active sites on the coffee wastes (COF). With the enhancement of the agitation speed, the adsorption increases, reaching a rate-limit over which there is no significant change. So, the optimum agitation rate found was $140 \mathrm{rpm}$. Also, an interesting point is the change of agitation-behavior between real and synthetic effluent. Fig. 6 showed that rate of agitation influenced stronger the decolorization from real samples (real: from $9 \%$ for $60 \mathrm{rpm}$ to $23 \%$ for $140 \mathrm{rpm}$; synthetic: from $24 \%$ for $60 \mathrm{rpm}$ to $28 \%$ for $140 \mathrm{rpm}$ ). The impurities and dye auxiliaries (which co-existed in real dyeing effluent), in line with the strong salinity $(\sim 1 \mathrm{~mol} / \mathrm{L} \mathrm{NaCl})$ in real conditions prevented the dye molecules from interacting with the active adsorption sites of COF. Increasing the rate of agitation, the molecules existed in solution (dyes, salts, auxiliaries) were set in more rapid motion; so, the opportunity to interact the adsorption site of COF with the dye was increased.

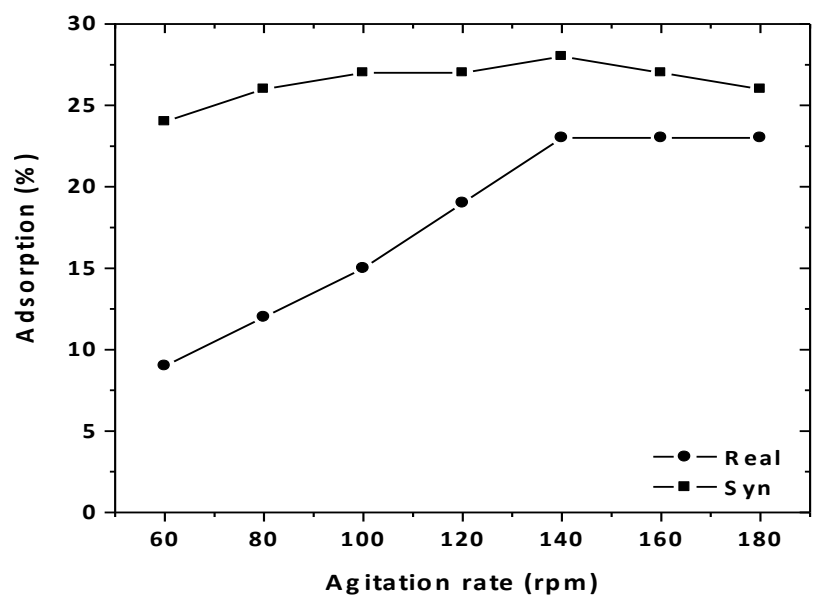

Fig. 6. Effect of agitation on decolorization of real and synthetic dyeing solutions with $\mathrm{COF}(\mathrm{pH}=$ free, $700 \mathrm{mg} / \mathrm{L}$ total dye concentration; $1 \mathrm{~g} / \mathrm{L}$ adsorbent; $\mathrm{T}=25^{\circ} \mathrm{C} ; 60-180 \mathrm{rpm} ; 24 \mathrm{~h}$ contact).

\subsubsection{Effect of initial dye concentration - isotherms (synthetic samples)}

Fig. 7 presents the isotherms resulted from the decolorization of synthetic effluent at two $\mathrm{pH}$ values (in order to compare the $\mathrm{Q}_{\mathrm{m}}$ of low-cost $\mathrm{COF}$ at natural and optimum $\mathrm{pH}$ value). Table 2 reports the maximum adsorption capacities $\left(\mathrm{Q}_{\mathrm{m}}\right)$ and the other isothermal parameters resulted from the fitting. The correlation coefficients $\left(\mathrm{R}^{2}\right)$ confirmed that both L-F and Langmuir models fitted the experimental data with high correlation (LF: $\mathrm{R}^{2} \sim 0.999$; Langmuir: $\left.\mathrm{R}^{2} \sim 0.997\right)$. The $\mathrm{Q}_{\mathrm{m}}$ for total dye removal at $25{ }^{\circ} \mathrm{C}$ was $241 \mathrm{mg} / \mathrm{g}(\mathrm{pH}=2)$ and $179 \mathrm{mg} / \mathrm{g}$ $(\mathrm{pH}=10)$. The reduction of capacity was only $60 \mathrm{mg} / \mathrm{g}$.

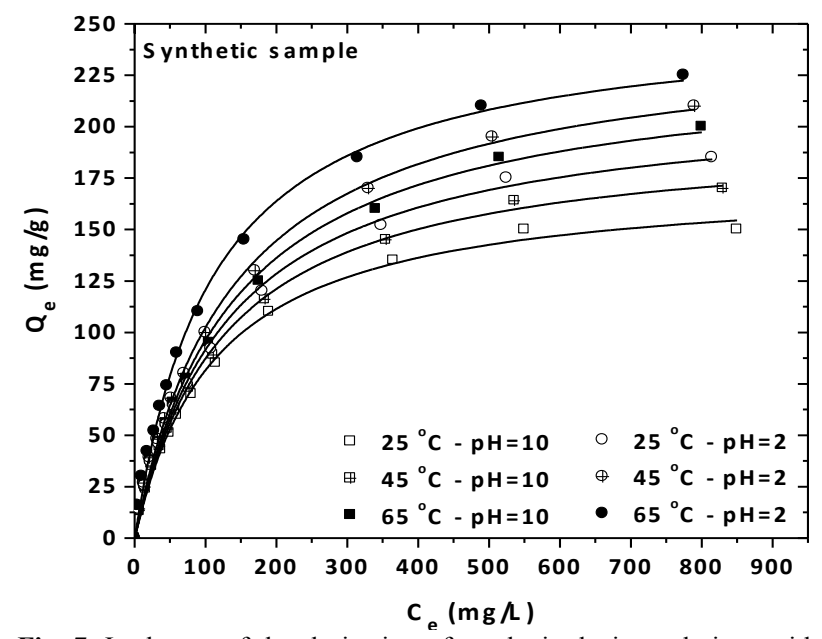

Fig. 7. Isotherms of decolorization of synthetic dyeing solutions with 
$\mathrm{COF}(\mathrm{pH}=2,10 ; 0-1000 \mathrm{mg} / \mathrm{L}$ total dye concentration; $1 \mathrm{~g} / \mathrm{L}$ adsorbent; $\mathrm{T}=25,45,65^{\circ} \mathrm{C} ; 140 \mathrm{rpm} ; 24 \mathrm{~h}$ contact).

Table 2

Equilibrium parameters for the adsorption of dyes from synthetic effluent onto $\mathrm{COF}$ at optimum $\mathrm{pH}=2$ and natural (non-adjusted) $\mathrm{pH} \sim 10$ at 25,45 , and $65^{\circ} \mathrm{C}$.

\begin{tabular}{|c|c|c|c|c|c|c|c|c|c|c|c|}
\hline \multirow[b]{2}{*}{$\begin{array}{l}\text { Synth } \\
\text { etic } \\
\text { sampl } \\
\text { e }\end{array}$} & \multirow[b]{2}{*}{$\begin{array}{l}\mathrm{T} \\
\circ \\
\mathrm{C}\end{array}$} & \multicolumn{3}{|c|}{ Langmuir equation } & \multicolumn{3}{|c|}{ Freundlich equation } & \multicolumn{4}{|c|}{$\begin{array}{l}\text { Langmuir-Freundlich (L-F) } \\
\text { equation }\end{array}$} \\
\hline & & $\begin{array}{c}\mathrm{Q}_{\mathrm{m}} \\
\mathrm{mg} \\
/ \mathrm{g}\end{array}$ & $\begin{array}{c}\mathrm{K}_{\mathrm{L}} \\
\mathrm{L} / \mathrm{m} \\
\mathrm{g}\end{array}$ & $\begin{array}{l}\mathrm{R}^{2} \\
-\end{array}$ & 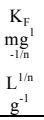 & n & $\begin{array}{l}\mathrm{R}^{2} \\
-\end{array}$ & $\begin{array}{c}\mathrm{Q}_{\mathrm{m}} \\
\mathrm{mg} \\
/ \mathrm{g}\end{array}$ & $\begin{array}{c}\mathrm{K}_{\mathrm{LF}} \\
(\mathrm{L} / \mathrm{mg} \\
)^{1 / \mathrm{b}}\end{array}$ & b & $\begin{array}{l}\mathrm{R}^{2} \\
-\end{array}$ \\
\hline $\mathrm{pH}=1$ & 2 & 175 & 0.00 & 0.9 & 11. & 2.5 & 0.9 & 179 & 0.008 & 0.9 & 0.9 \\
\hline \multirow{5}{*}{0} & 5 & & 88 & 97 & 83 & 3 & 57 & & 2 & 57 & 97 \\
\hline & 4 & 197 & 0.00 & 0.9 & 11. & 2.4 & 0.9 & 212 & 0.006 & 0.8 & 0.9 \\
\hline & 5 & & 80 & 97 & 59 & 1 & 69 & & 6 & 98 & 99 \\
\hline & 6 & 232 & 0.00 & 0.9 & 11. & 2.2 & 0.9 & 269 & 0.004 & 0.8 & 0.9 \\
\hline & 5 & & 71 & 97 & 44 & 7 & 80 & & 7 & 28 & 99 \\
\hline \multirow[t]{6}{*}{$\mathrm{pH}=2$} & 2 & 214 & 0.00 & 0.9 & 11. & 2.3 & 0.9 & 241 & 0.005 & 0.8 & 0.9 \\
\hline & 5 & & 75 & 97 & 47 & 4 & 76 & & 4 & 50 & 99 \\
\hline & 4 & 245 & 0.00 & 0.9 & 12. & 2.2 & 0.9 & 278 & 0.005 & 0.8 & 0.9 \\
\hline & 5 & & 72 & 97 & 08 & 7 & 78 & & 1 & 48 & 99 \\
\hline & 6 & 254 & 0.00 & 0.9 & 15. & 2.4 & 0.9 & 287 & 0.006 & 0.8 & 0.9 \\
\hline & 5 & & 91 & 97 & 85 & 3 & 75 & & 4 & 35 & 99 \\
\hline
\end{tabular}

In general, the equilibrium dye uptake was affected by the initial dye concentration using constant dosage of COF $(1 \mathrm{~g} / \mathrm{L})$. At low initial concentrations, the adsorption of dyes seemed to be very intense and reached equilibrium rapidly. This phenomenon indicated the possibility of the formation of monolayer coverage of dye molecules at the outer interface of COF. Furthermore, for low total dye concentrations $(0-50 \mathrm{mg} / \mathrm{L})$ the ratio of initial number of dye molecules to the available adsorption sites is low and subsequently the fractional adsorption becomes independent on initial concentration [37,38]. According to BET classification [39], I-type isotherms represents unimolecular adsorption and applies to non-porous, microporous and adsorbents with small pore sizes (not significantly better than the molecular diameter of the adsorbate). So, the shapes of curves (Fig. 7) indicated that the isotherms for the adsorbent-dye systems studied were I-Type and characterized by a high degree of adsorption at low concentrations. At higher concentrations, the available adsorption sites were lower and subsequently the adsorption depended on the initial concentration of dye. As a matter of fact, the diffusion of exchanging molecules within COF particles may govern the adsorption rate at higher initial concentrations.

The effect of temperature on equilibrium is also presented through isotherms curves (Fig. 7) .The adsorption behavior is similar for both $\mathrm{pH}$-conditions of synthetic effluents: increasing the temperature of process from 25 to $65{ }^{\circ} \mathrm{C}$, an increase of the adsorption capacity (dye uptake) is observed. Similar results were already published [5].

\subsubsection{Thermodynamics}

The parameters of $\Delta \mathrm{H}^{0}$ and $\Delta \mathrm{S}^{0}$ were calculated from the slop and intercept of the plot between $\ln \left(\mathrm{K}_{\mathrm{c}}\right)$ versus $(1 / \mathrm{T})$ $\left(R^{2}>0.990\right.$, data not shown). These parameters, at selected total dye concentrations and all temperatures, are given in Table 3 for synthetic effluents $(\mathrm{pH}=2$ and $\mathrm{pH}=10)$. The positive values of $\Delta \mathrm{H}^{0}$ suggest the endothermic nature of the process. The negative values of $\Delta \mathrm{G}^{0}$ (initial total dye concentrations $<500 \mathrm{mg} / \mathrm{L}$ ) suggest that the process is spontaneous with high preference for dye molecules. In the case of high initial total dye concentrations $\left(\mathrm{C}_{0}>500 \mathrm{mg} / \mathrm{L}\right)$, enthalpy is positive presenting non-spontaneous behavior. Since the adsorption is endothermic, the amount adsorbed at equilibrium is increased with increasing temperature. The positive values of $\Delta S^{0}$ show the increased randomness at the solid/liquid interface. During the adsorption, the coordinated water molecules (which are displaced by the dye molecules) gain more translational entropy than is lost by the dye molecules, resulting in increased randomness in the dyeadsorbent interaction $[31,40]$.

\section{Table 3}

Thermodynamic parameters for the decolorization of synthetic effluent with COF.

\begin{tabular}{|c|c|c|c|c|c|c|c|}
\hline Synthetic sample & $\begin{array}{c}\mathrm{C}_{0} \\
\mathrm{mg} / \mathrm{L} \\
\end{array}$ & $\begin{array}{l}\mathrm{T} \\
\mathrm{K} \\
\end{array}$ & $\begin{array}{c}\mathrm{Q}_{\mathrm{e}} \\
\mathrm{mg} / \mathrm{g}\end{array}$ & $\begin{array}{c}\mathrm{K}_{\mathrm{c}} \\
- \\
\end{array}$ & $\begin{array}{c}\Delta \mathrm{G}^{0} \\
\mathrm{~kJ} / \mathrm{mol}\end{array}$ & $\begin{array}{c}\Delta \mathrm{H}^{0} \\
\mathrm{~kJ} / \mathrm{mol}\end{array}$ & $\begin{array}{c}\Delta \mathrm{S}^{0} \\
\mathrm{~kJ} / \mathrm{mol} \mathrm{K}\end{array}$ \\
\hline $\mathrm{pH}=2$ & 20 & 298 & 13.72 & 2.17 & $\begin{array}{c}-1.92 \\
\end{array}$ & +5.79 & +1.513 \\
\hline \multirow[t]{11}{*}{ (optimum) } & & 318 & 14.21 & 2.45 & -2.37 & & \\
\hline & & 338 & 16.02 & 4.00 & -3.90 & & \\
\hline & 100 & 298 & 55.01 & 1.22 & -0.50 & +3.32 & +0.935 \\
\hline & & 318 & 57.98 & 1.38 & -0.85 & & \\
\hline & & 338 & 64.04 & 1.78 & -1.62 & & \\
\hline & 500 & 298 & 152.11 & 0.44 & 2.05 & +1.68 & +0.746 \\
\hline & & 318 & 170.05 & 0.52 & 1.75 & & \\
\hline & & 338 & 184.97 & 0.59 & 1.50 & & \\
\hline & 1000 & 298 & 185.02 & 0.23 & 3.67 & +0.61 & +0.622 \\
\hline & & 318 & 209.98 & 0.27 & 3.50 & & \\
\hline & & 338 & 225.02 & 0.29 & 3.48 & & \\
\hline \multirow{13}{*}{$\begin{array}{l}\mathrm{pH} \sim 10 \\
\text { (natural/non- } \\
\text { adjusted) }\end{array}$} & 20 & 298 & 13.00 & 1.86 & -1.53 & +2.53 & +0.873 \\
\hline & & 318 & & & & & \\
\hline & & & 13.41 & 2.03 & -1.87 & & \\
\hline & & 338 & 14.04 & 2.33 & -2.38 & & \\
\hline & 100 & 298 & 51.01 & 1.04 & -0.10 & +1.72 & +0.603 \\
\hline & & 318 & 52.95 & 1.13 & -0.32 & & \\
\hline & & 338 & 56.04 & 1.27 & -0.68 & & \\
\hline & 500 & 298 & 135.01 & 0.37 & 2.46 & +1.19 & +0.571 \\
\hline & & 318 & 145.07 & 0.41 & 2.37 & & \\
\hline & & 338 & 160.02 & 0.47 & 2.12 & & \\
\hline & 1000 & 298 & 149.96 & 0.18 & 4.30 & +1.02 & +0.503 \\
\hline & & 318 & 170.07 & 0.20 & 4.19 & & \\
\hline & & 338 & 200.02 & 0.25 & 3.90 & & \\
\hline
\end{tabular}

Another interesting finding was that $\Delta \mathrm{H}^{0}$ and $\Delta \mathrm{S}^{0}$ showed a decrease with increasing initial concentration and amount adsorbed. This effect could be attributed to: (i) the energetic heterogeneity of the surface, and (ii) possible dyedye interactions. The dependence of heat of adsorption with surface coverage is usually observed to display the adsorbent-adsorbate interactions followed by adsorbateadsorbate interactions [41]. At low concentrations, hence at low $\mathrm{Q}_{\mathrm{e}}$, the adsorption sites having the highest affinity for dyes are occupied first, while then, with increasing $Q_{e}$, the remaining sites with lower affinity are progressively occupied. The variation of heat of adsorption with surface loading can be also attributed to the possibility of lateral interactions between dye molecules. It is well known that ionic dyes trend to aggregate in dilute solutions, leading to dimmer formation [42]. It is supposed that dimmer formation in solution is mainly due to hydrophobic interactions or permanent-transition dipole moments [42]. Although dyes are very individualistic as structure, certain broad rules are well established regarding their dimerization. The probability increases with an increase of dye concentration or ionic strength; it will decrease with temperature rising or organic solvents adding [42].

\subsubsection{Effect of dosage of adsorbent (real samples)}

Fig. 8 illustrates data from real textile effluents by varying the mass of adsorbent. The $\mathrm{pH}$ of the textile effluent was measured $(\mathrm{pH} \sim 10)$ and left without adjustment. The total residual dye content was expressed both in concentration $(\mathrm{mg} / \mathrm{L})$ and ADMI units $[32,33]$. Given the high dye content of real sample and the ADMI technology, the reduction in $\sim 300$ ADMI units is a very sufficient level $[1,6,7,32]$. It is obvious that increasing the adsorbent's dosage, the decolorization is improved. For $10 \mathrm{~g} / \mathrm{L}$ as dosage, a full decolorization is observed. So, for this purpose, this dosage was selected for the next column experiments. 


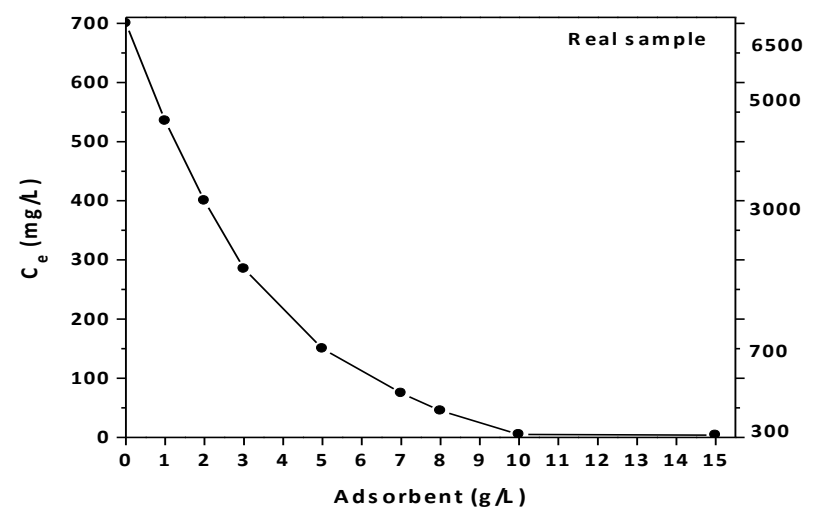

Fig. 8. Effect of mass of adsorbent (COF) on decolorization of real textile effluents $(\mathrm{pH}=$ free, $700 \mathrm{mg} / \mathrm{L}$ total dye concentration; $1 \mathrm{~g} / \mathrm{L}$ adsorbent; $\mathrm{T}=25^{\circ} \mathrm{C} ; 60-140 \mathrm{rpm} ; 24 \mathrm{~h}$ contact).

\subsubsection{Reuse potential (desorption and cycles)}

Before the investigation of reuse, desorption experiments were carried out to find the optimum $\mathrm{pH}$-desorption conditions. The contrast phenomenon from the adsorption is observed (data non shown), presenting the highest desorption percentage in alkaline conditions (92\%). It is generally surprising to get a good adsorption and desorption at the same $\mathrm{pH}$, given the adsorption experiments for real effluents were performed at natural $\mathrm{pH}(\sim 10)$. However, there was a significant difference between the two processes with respect to the ionic strength: adsorption was realized in the presence of $\sim 1 \mathrm{~mol} / \mathrm{L} \mathrm{NaCl}$, while desorption in its absence. The high electrolyte content generates high osmotic pressure in the bulk and causes more sodium ion penetration in the inner of adsorbent, which eventually helps/favours dye molecule uptake. In the contrary, the absence of electrolyte reverses the mass transfer from the solid phase to the bulk [5].

To investigate the reuse of the materials used, sequential adsorption-desorption experiments in batch mode were conducted for 10 cycles. Fig. 9 showed that the reduction in adsorption percentages from the $1^{\text {st }}$ to $10^{\text {th }}$ cycle was $4 \%$ for COF. This decrease occurred can be attributed to several reasons as: (i) a progressive saturation of the active adsorption sites/groups by dye molecules, (ii) a degradation of material due to extreme $\mathrm{pH}$ conditions, (iii) a progressive blocking of the active sites of the adsorbent by possible impurities caused a slight decrease in the adsorption potential.

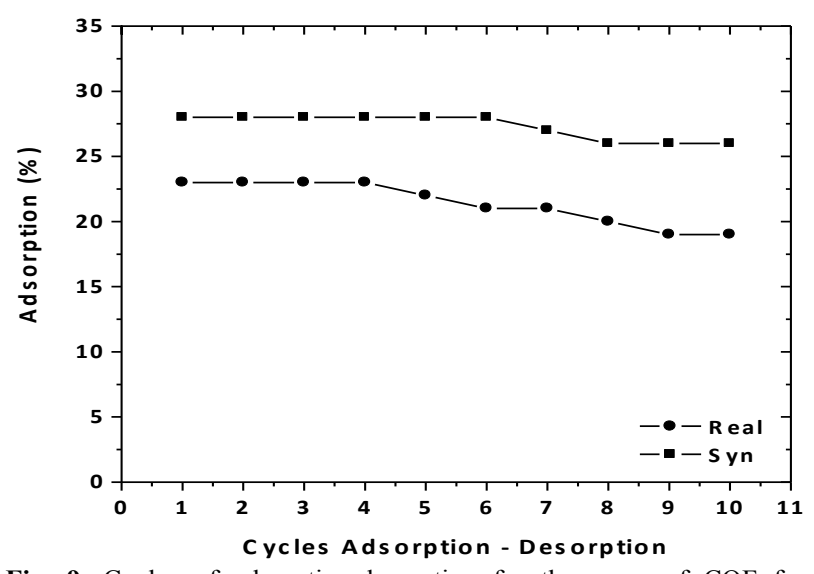

Fig. 9. Cycles of adsorption-desorption for the reuse of COF for decolorization of real and synthetic textile effluent $\left(\mathrm{pH}_{\mathrm{ads}}=\right.$ free; $\mathrm{pH}_{\mathrm{des}}=10 ; 1 \mathrm{~g} / \mathrm{L}$ adsorbent; $\mathrm{T}=25^{\circ} \mathrm{C} ; 140 \mathrm{rpm} ; 24 \mathrm{~h}$ contact $)$.

\subsection{Fixed-bed systems}

In this study, the primary was to firstly optimize the batch adsorption conditions and then attempt to apply them in fixed-bed systems. It is a great of interest to achieve a continuous system of decolorization of industrial dyeing wastewaters using low-cost adsorbents. So, the whole concept was mainly based on the reuse/regeneration step in columns just after the adsorption process.

To set up a fixed-bed system, it is necessary to examine the swelling behaviour of the adsorbents used, in order to prevent fouling phenomena inside the column. For the swelling experiments, $1 \mathrm{~g}$ of COF was immersed in deionized water to be swollen for $24 \mathrm{~h}$. The material was judged to be completely swollen after sequential measurements, until there was no further mass increase. Subsequently, it was separated from water by filtration and the excess of water has removed carefully by a filter paper. The swollen samples were weighted and the swelling percentage S (\%) was calculated by Eq. (19):

$\mathrm{S}=\left(\frac{\mathrm{M}_{\mathrm{t}}-\mathrm{M}_{0}}{\mathrm{M}_{0}}\right) \cdot 100 \%$

where $\mathrm{M}_{\mathrm{t}}(\mathrm{g})$ is the mass of the swollen COF at time $\mathrm{t}$, and $\mathrm{M}_{0}(\mathrm{~g})$ is its initial mass before swelling.

According to the above experiments, the swelling percentages were found: $46,48,45,55,52,51 \%$ at $\mathrm{pH}=2,4$, $6,8,10$, and 12 , respectively. So, a useful finding is that $\mathrm{COF}$ is not be affected by the change of $\mathrm{pH}$ of solution. At the crucial $\mathrm{pH}=10$ (where is the natural $\mathrm{pH}$ value of real dyeing wastewaters) the approximate swelling percentage was $50 \%$.

Although the optimum $\mathrm{pH}$ found was 2, the real sample was left to be treated without adjustment of its $\mathrm{pH}$ to eliminate the cost of the process (saving cost of reagents) and simulate the real/industrial conditions of real samples. So, experiments with $2 \mathrm{~mL} / \mathrm{min}$ as flow rate were performed.

Fig. 10 illustrates the respective breakthrough curves including continuous adsorption and desorption process. The bed (length: $8 \mathrm{~cm} ; 0.4 \mathrm{~mm}$ radius; plexiglas) was filled with $10 \mathrm{~g}$ COF. It was prepared $10 \mathrm{~L}$ of real industrial sample, but the adsorption was process was stopped after the end of 24 h. In this time, approximately $2.8 \mathrm{~L}$ was entered from the column. After this, a desorption process was directly begun with the aqueous solution of $\mathrm{NaOH}$ with $\mathrm{pH}=12$, keeping the same flow rate $(2 \mathrm{~mL} / \mathrm{min})$ for the eluant. On the contrary, the desorption phase was rapid $(\sim 2 \mathrm{~h})$, leaving a small percentage of residual total dye concentration $(\sim 5 \%)$. After the $1^{\text {st }}$ cycle of reuse, a $2^{\text {nd }}$ and $3^{\text {rd }}$ one were performed with the same procedure. The total dye residual concentration after the last cycle was approximately $15 \mathrm{mg} / \mathrm{L}$ (Fig. 10). In general, the whole procedure was realized not to make a quantitative study for fixed-bed adsorption with modeling and simulation theories, but to achieve a first combination of data between batch and continuous modes. Furthermore, the most promising was the cost potential of this attempt, observing that after 3 cycles of reuse, $\sim 4 \mathrm{~g}$ of total dye content was removed from $\mathrm{COF}$. 


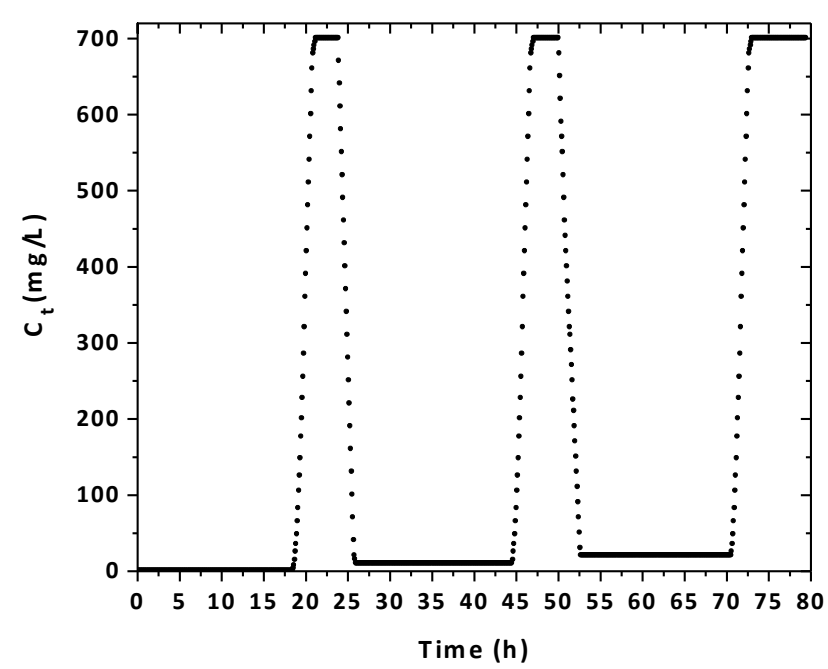

Fig. 10. Breakthrough curves for continuous adsorption-desorption processes in fixed-bed systems.

\subsection{Cost potential of adsorbents}

Some important parameters have to be considered in order to select a suitable adsorbent: (i) low cost; (ii) capacity and rate of adsorption; (iii) efficiency for removal of a wide variety of target pollutants; (iv) granular type with high physical strength; (v) ability to be regenerated [10]; (vi) application in columns for continuous experiments.

So, in this study, COF adsorbents used as low-cost materials (in particular as zero-cost adsorbents), obtained from wastes of café. It is true that there are materials with higher adsorption capacity as activated carbons $(\sim 500 \mathrm{mg} / \mathrm{g})$, which are quite expensive. COF adsorbents presented some promising points: (i) high reuse potential (up to 10 cycles with only $4 \%$ in dye loss), (ii) easy regeneration step (by a washing solvent since the interaction between the pollutant and adsorbent is driven mainly by electrostatic, hydrophobic and ion-exchange interactions); (iii) non-adjustment of $\mathrm{pH}$ for real effluents $(\mathrm{pH} \sim 10)$ saving money and energy, and (iv) nearly zero-cost of their preparation (non-modified forms). All the aforementioned points can give a strong costpotential for further use of these adsorbents even in real industrial-scale system. Based on the latter, the attempt to use COF in fixed-bed systems was proved the great potential of the low-cost adsorbents. The loaded COF materials easily desorbed their dye content and re-set up for the next cycle of adsorption.

\section{Conclusions}

kyzasThe decolorization of real textile wastewaters was studied with coffee wastes (COF) as low-cost adsorbents. The optimum $\mathrm{pH}$ found after adsorption experiments was $\mathrm{pH}=2$ for synthetic dyeing effluents, while experiments in free $\mathrm{pH}$ (non-adjusted) were carried out for real effluents. Equilibrium data were fitted to the Langmuir, Freundlich and Langmuir-Freundlich (L-F) model. The best correlation was for L-F model $\left(\mathrm{R}^{2} \sim 0.999\right)$. The calculated maximum adsorption capacities $\left(\mathrm{Q}_{\mathrm{m}}\right)$ for total dye removal at $25{ }^{\circ} \mathrm{C}$ was $241 \mathrm{mg} / \mathrm{g} \quad(\mathrm{pH}=2)$ and $179 \quad \mathrm{mg} / \mathrm{g} \quad(\mathrm{pH}=10)$. Thermodynamic analysis was realized, where the positive values of $\Delta \mathrm{H}^{0}$ suggest the endothermic nature of the process, the negative values of $\Delta \mathrm{G}^{0}$ suggest that the process is spontaneous with high preference for dye molecules, and the positive values of $\Delta \mathrm{S}^{0}$ show the increased randomness at the solid/liquid interface. Kinetic data were fitted to the pseudofirst, -second and -third order model. The best correlation was for pseudo-first order equation. The optimum agitation rate for the current adsorption phenomenon was determined to be $140 \mathrm{rpm}$. The optimum desorption $\mathrm{pH}$ found was $\mathrm{pH}=10$, and after 10 cycles of reuse, the reduction in adsorption percentages from the $1^{\text {st }}$ to $10^{\text {th }}$ cycle was approximately $4 \%$ for COF adsorbents. Increasing the mass of COF adsorbents, a strong increase in total dye removal occurred. For $10 \mathrm{~g} / \mathrm{L}$ as dosage, a full decolorization is observed. For the fixed-bed systems, the most promising was that after 3 cycles of reuse, $\sim 4 \mathrm{~g}$ of total dye content was removed from $\mathrm{COF}$, presenting a strong cost potential.

\section{Acknowledgements}

The authors gratefully acknowledge: (i) Mr. Ioannis Kyridis (director/owner of the "Dyeing-Finishing mills of Thessaloniki, Greece") who provided the real industrial textile wastewaters used in this study; (ii) the owners of the local café "Bliss" (Thessaloniki, Greece), who kindly donated the real wastes of coffee (collected after roasting a special variety of coffee drinks, "Greek coffee" drinks); (iii) the present work is a part of result in the framework of NSRF (National Strategic Reference Framework). Thalis "NanocapillaryC" (MIS 375233) of the Kavala Institute of Technology is co-financed by Greece and the European Union in the frame of operational program "Education and lifelong learning investing in knowledge society" of Ministry of Education, Lifelong learning and religious affairs (NSRF 2007-2013).

\section{References}

1. Mishra, G., Tripathy, M., 1993. A critical review of the treatments for decolourization of textile effluent. Colourage 40, 35-38.

2. Blackburn, R.S., 2004. Natural polysaccharides and their interaction with dye molecules: Applications in effluent treatment. Environ. Sci. Technol. 38, 4905-4909.

3. Sun, Q., Yang, L., 2003. The adsorption of basic dyes from aqueous solution on modified peat-resin particle. Water Res. 37, 1535-1544.

4. Allègre, C, Moulin, P., Maisseu, M., Chrabit, F., 2006. Treatment and reuse of reactive dyeing effluents. J. Membrane Sci. 269, 15-34.

5. Kyzas, G.Z., Kostoglou, M., Vassiliou, A.A., Lazaridis, N.K., 2011. Treatment of real effluents from dyeing reactor: Experimental and modeling approach by adsorption onto chitosan. Chem. Eng. J. 168, 577-585.

6. Zollinger, H., 2003. Color Chemistry, Wiley-VCH, Zurich.
7. O’Neill, C., Hawkes, F.R., Hawkes, D.L., Lourenço, N.D., Pinheiro, H.M., Delée, W., 1999. Colour in textile effluents-sources, measurement, discharge consents and simulation: a review. J. Chem. Technol. Biot. 74, 1009-1018.

8. Hessel, C., Allègre, C., Maisseu, M., Charbit, F., Moulin, P., 2007. Guidelines and legislation for dye house effluents. J. Environ. Manage. 83, 171-180.

9. Al-Degs, Y.S., Khraisheh, M.A.M., Allen, S.J., Ahmad, M.N., 2009. Adsorption characteristics of reactive dyes in columns of activated carbon. J. Hazard. Mater. 165, 944-949.

10. Crini, G., 2006. Non-conventional low-cost adsorbents for dye removal: A review. Bioresour. Technol. 97, 1061-1085.

11. Kaushik, C.P., Tuteja, R., Kaushik, N., Sharma, J.K., 2009. Minimization of organic chemical load in direct dyes effluent using low cost adsorbents. Chem. Eng. J. 155, 234-240. 
12. Fiorentin, L.D., Trigueros, D.E.G., Módenes, A.N., EspinozaQuiñones, F.R., Pereira, N.C., Barros, S. T.D., Santos, O.A.A., 2010. Biosorption of reactive blue 5G dye onto drying orange bagasse in batch system: Kinetic and equilibrium modelling. Chem. Eng. J. 163, 68-77.

13. Konaganti, V.K., Kota, R., Patil, S., Madras, G., 2010. Adsorption of anionic dyes on chitosan grafted poly(alkyl methacrylate). Chem. Eng. J. 158, 393-401.

14. Boonamnuayvitaya, V., Chaiya, C., Tanthapanichakoon, W., Jarudilokkul, S., 2004. Removal of heavy metals by adsorbent prepared from pyrolyzed coffee residues and clay. Sep. Purif. Technol. 35, 11-22.

15. Azouaou, N., Sadaoui, Z., Djaafri, A., Mokaddem H., 2010. Adsorption of cadmium from aqueous solution onto untreated coffee grounds: Equilibrium, kinetics and thermodynamics. J. Hazard. Mater. 184, 126-134.

16. Oliveira, L.S., Franca, A.S., Alves, T.M., Rocha, S.D.F., 2008. Evaluation of untreated coffee husks as potential biosorbents for treatment of dye contaminated waters. J. Hazard. Mater. 155, 507512 .

17. Franca, A.S., Oliveira, L.S., Ferreira, M.E., 2009. Kinetics and equilibrium studies of methylene blue adsorption by spent coffee grounds. Desalination 249, 267-272.

18. Baek, M.-H., Olakitan Ijagbemi, C., O, S.-J., Kim, D.-S., 2010. Removal of malachite green from aqueous solution using degreased coffee bean. J. Hazard. Mater. 176, 820-828.

19. Ahmad, M.A., Rahman, N.K., 2011. Equilibrium, kinetics and thermodynamic of Remazol Brilliant Orange 3R dye adsorption on coffee husk-based activated carbon. Chem. Eng. J. 170, 154-161.

20. Safarik, I., Horska, K., Svobodova, B., Safarikova, M., 2012. Magnetically modified spent coffee grounds for dyes removal. Eur. Food. Res. Technol. http://dx.doi.org/10.1007/s00217-011-1641-3.

21. Tokimoto, T., Kawasaki, N., Nakamura, T., Akutagawa, J., Tanada, S., 2005. Removal of lead ions in drinking water by coffee grounds as vegetable biomass. J. Colloid Interf. Sci. 281, 56-61.

22. Mussatto, S.I., Machado, E.M.S., Martins, S., Teixeira, J.A., 2011. Production, composition and application of coffee and its industrial residues. Food Bioprocess Tech. 4, 661-672.

23. Valdes, H., Sanchez-Polo, M., Rivera-Utrilla, J., Zaror, C.A., 2002. Effect of ozone treatment on surface properties of activated carbon. Langmuir 18, 2111-2116.

24. Boehm, H.P., 1966. Chemical identification of surface groups. Adv. Catal. 16, 179-274

25. Ho, Y.S., Ng, J.C.Y., McKay, G., 2000. Kinetics of pollutant sorption by biosorbents: Review. Sep. Purif. Method. 29, 89-232.

26. Langmuir, I., 1918. The adsorption of gases on plane surface of glass, mica and platinum. J. Am. Chem. Soc. 40, 1361-1368.

27. Freundlich, H.M.F., 1906. Über die adsorption in lösungen (Adsorption in solution). Z. Phys. Chem. 57, 384-470.
28. Tien, C., 1994. Adsorption Calculation and Modeling; ButterworthHeinemann, Boston, USA, 1994, p. 27.

29. Smith, J.M., Van Ness, H.C., 1987. Introduction to Chemical Engineering Thermodynamics, 4th ed. McGraw-Hill, Singapore.

30. Beer, A., 1852. Bestimmung der absorption des rothen lichts in farbigen flussigketiten. Ann. Physik. Chem. 86, 78-88

31. Kyzas, G.Z., Bikiaris, D.N., Lazaridis, N.K., 2009. Selective separation of basic and reactive dyes by molecularly imprinted polymers (MIPs). Chem. Eng. J. 149, 263-272.

32. Allen, W., Presscott, W.B., Derby, R.E., Garland, C.E., Peret, J.M., Saltzman, M., 1973. Determination of color of water and wastewater by means of ADMI color values, Proceedings of the 27th Purdue Industrial Wastewater Conference, Part 2, Purdue University, Lafayette Indiana, pp. 661-675.

33. McLaren, K., 1970. The Adams-Nickerson colour-difference formula. JSDC 86, 354-356.

34. Kyzas, G.Z., Lazaridis, N.K., Mitropoulos, A.Ch., 2012. Removal of dyes from aqueous solutions with untreated coffee residues as potential low-cost adsorbents: Equilibrium, reuse and thermodynamic approach, Chem. Eng. J. 189-190, 148-159.

35. Sakkayawong, N., Thiravetyan, P., Nakbanpote, W., 2005. Adsorption mechanism of synthetic reactive dye wastewater by chitosan. J. Colloid Interface Sci. 286, 36-42.

36. Wang, L., Wang, A., 2008. Adsorption properties of congo red from aqueous solution onto N,O-carboxymethyl-chitosan. Bioresour. Technol. 99, 1403-1408.

37. Chatterjee, S., Chatterjee, S., Chatterjee, B.P., Das, A.R., Guha, A.K., 2005. Adsorption of a model anionic dye, eosin Y, from aqueous solution by chitosan hydrobeads. J. Colloid. Interf. Sci. 288, 30-35.

38. Chiou, M.S., Chuang, G.S., 2006. Competitive adsorption of dye metanil yellow in acidic solutions on chemically cross-linked chitosan beads. Chemosphere 62, 731-740.

39. Brunauer, S., Deming, L.S., Deming, W.E., Teller, E., 1940. A theory of van der Waals adsorption of gases. J. Am. Chem. Soc. 62, 1723-1732.

40. Unnithan, M.R., Anirudhan, T.S., 2001. The kinetics and thermodynamics of sorption of chromium (VI) onto the iron(III) complex of a carboxylated polyacrylamide-grafted sawdust. Ind. Eng. Chem. Res. 40, 2693-2701.

41. Srivastava, V.C., Mall, I.D., Mishra, I.M., 2007. Adsorption thermodynamics and isosteric heat of adsorption of toxic metal ions onto bagasse fly ash (BFA) and rice husk ash (RHA). Chem. Eng. J. 132, 267-278.

42. Niazi, A., Yazdanipour, A., Ghasemi, J., Kubista, M., 2006. Spectrophotometric and thermodynamic study on the dimerization equilibrium of ionic dyes in water by chemometrics method. Spectrochim. Acta Part A 65, 73-78. 